\title{
Education of Healthcare Personnel Working with Pediatric Patients During COVID-19 Pandemic within the Framework of Infection Control
}

\author{
COVID-19 Pandemisinde Enfeksiyon Kontrol Çalışmaları Çerçevesinde \\ Çocuk Hastalarla Çalışan Sağlık Personeli Eğitimi
}

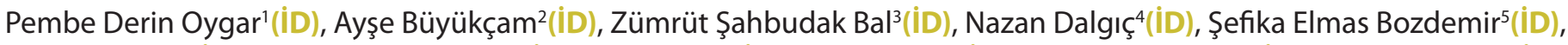

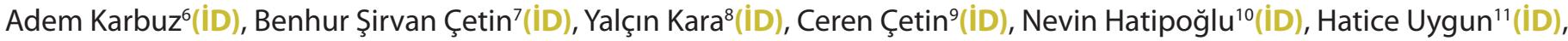

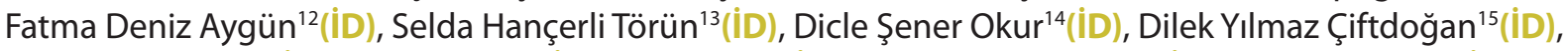

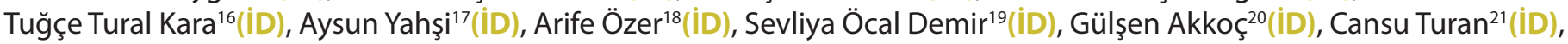

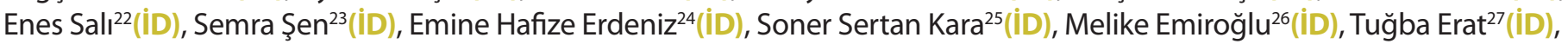
Hacer Aktürk ${ }^{28}$ (ID), Sibel Laçinel Gürlevik'(ID), Murat Sütçü̈29(ID), Zeynep Gökçe Gayretli Aydınº(iD), Başak Yıldız Atikan ${ }^{31}$ (ID),

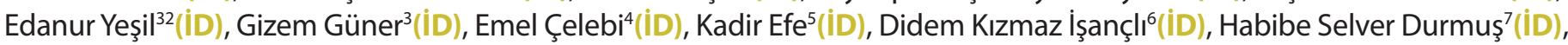

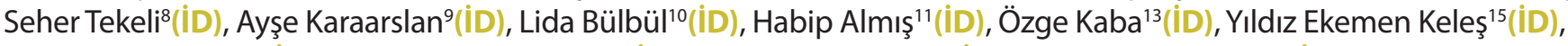

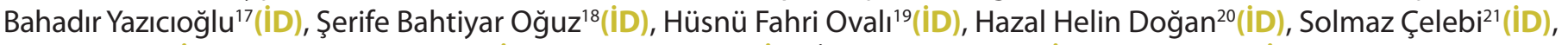

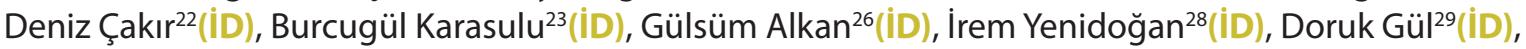

Burcu Parıltan Küçükalioğlu30(iD), Gülhadiye Avcu'31(iD), Musa Gürel Kukul'(iD), Melis Bilen(iD), Belma Yaşar(iD),

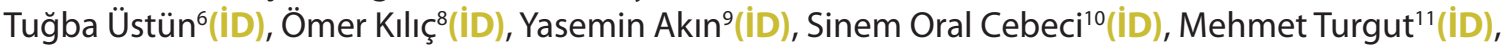

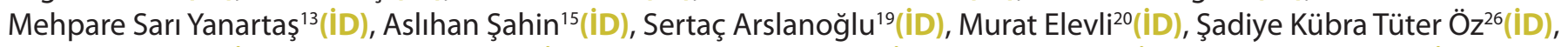

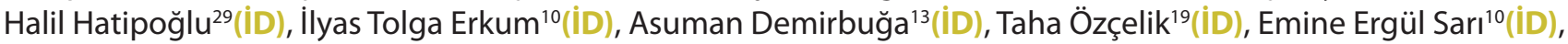
Gökhan Akkuş ${ }^{19}\left(\right.$ ID ), Sadık Sami Hatipoğlu' ${ }^{10}$ (iD), Ener Çağrı Dinleyicis(iD), Mustafa Hacımustafaoğlu²1(iD), Ferda Özkınay ${ }^{3}$ (ID), Zafer Kurugöl3(iD), Ali Bülent Cengiz'(iD), Ayper Somer³(iD), Hasan Tezer³(iD), Ateş Kara'(iD)

${ }^{1}$ Division of Pediatric Infectious Diseases, Department of Pediatrics, Hacettepe University School of Medicine, Ankara, Turkey

${ }^{2}$ Clinic of Pediatric Infectious Diseases, Gaziantep Cengiz Gökçek Maternity and Children Hospital, Gaziantep, Turkey

${ }^{3}$ Division of Pediatric Infectious Diseases, Department of Pediatrics, Ege University School of Medicine, Izmir, Turkey

${ }^{4}$ Clinic of Pediatric Infectious Diseases, Health Science University, Sariyer Hamidiye Etfal Training and Research Hospital, Istanbul, Turkey

${ }^{5}$ Clinic of Pediatric Infectious Diseases, Bursa Dörtçelik Children Hospital, Bursa, Turkey

${ }^{6}$ Clinic of Pediatric Infectious Diseases, Istanbul Prof. Dr. Cemil Tascioğlu City Hospital, İstanbul, Turkey

${ }^{7}$ Division of Pediatric Infectious Diseases, Department of Pediatrics, Erciyes University School of Medicine, Kayseri, Turkey

${ }^{8}$ Division of Pediatric Infectious Diseases, Department of Pediatrics, Osmangazi University School of Medicine, Eskişehir, Turkey

${ }^{9}$ Clinic of Pediatric Infectious Diseases, İstanbul Kartal Dr. Lütfü Kırdar State Hospital, Istanbul, Turkey

${ }^{10}$ Clinic of Pediatric Infectious Diseases, İstanbul Dr. Sadi Kanuni Sultan Süleyman Hospital, Istanbul, Turkey

${ }^{11}$ Division of Pediatric Infectious Diseases, Department of Pediatrics, Adıyaman University School of Medicine, Adıyaman, Turkey

${ }^{12}$ Clinic of Pediatric Infectious Diseases, İstanbul Kanuni Sultan Süleyman Hospital, Istanbul, Turkey

${ }^{13}$ Division of Pediatric Infectious Diseases, Department of Pediatrics, İstanbul University School of Medicine, Istanbul, Turkey

${ }^{14}$ Clinic of Pediatric Infectious Diseases, Denizli State Hospital, Denizli, Turkey

${ }^{15}$ Clinic of Pediatric Infectious Diseases, Health Science University, İmir Tepecik Training and Research Hospital, Izmir, Turkey

${ }^{16}$ Division of Pediatric Infectious Diseases, Department of Pediatrics, Akdeniz University School of Medicine, Antalya, Turkey

\footnotetext{
Correspondence Address/Yazışma Adresi

Ateş Kara

Hacettepe Üniversitesi Tıp Fakültesi,

Çocuk Sağlığı ve Hastalıkları Anabilim Dalı,

Çocuk Enfeksiyon Hastalıkları Bilim Dalı,

Ankara-Türkiye

E-mail: ateskara@hacettepe.edu.tr
} 
${ }^{17}$ Clinic of Pediatric Infectious Diseases, Health Science University, Samsun Training and Research Hospital, Samsun, Turkey

${ }^{18}$ Clinic of Pediatric Infectious Diseases, Van State Hospital, Van, Turkey

${ }^{19}$ Division of Pediatric Infectious Diseases, Department of Pediatrics, Istanbul Medeniyet University School of Medicine, İstanbul, Turkey

${ }^{20}$ Clinic of Pediatric Infectious Diseases, Health Science University İstanbul Haseki Training and Research Hospital, Istanbul, Turkey

${ }^{21}$ Division of Pediatric Infectious Diseases, Department of Pediatrics, Uludağ University School of Medicine, Bursa, Turkey

${ }^{22}$ Clinic of Pediatric Infectious Diseases, Health Science University, Ümraniye Training and Research Hospital, Istanbul, Turkey

${ }^{23}$ Division of Pediatric Infectious Diseases, Department of Pediatrics, Manisa Celal Bayar University School of Medicine, Manisa, Turkey

${ }^{24}$ Clinic of Pediatric Infectious Diseases, Health Science University, Erzurum Training and Research Hospital, Erzurum, Turkey

${ }^{25}$ Division of Pediatric Infectious Diseases, Department of Pediatrics, Aydın Adnan Menderes University School of Medicine, Aydın, Turkey

${ }^{26}$ Division of Pediatric Infectious Diseases, Department of Pediatrics, Selçuk University School of Medicine, Konya, Turkey

${ }^{27}$ Clinic of Pediatric Infectious Diseases, Health Science University Şanlıurfa Training and Research Hospital, Şanlıurfa, Turkey

${ }^{28}$ Division of Pediatric Infectious Diseases, Department of Pediatrics, Koç University School of Medicine, Istanbul, Turkey

${ }^{29}$ Division of Pediatric Infectious Diseases, Department of Pediatrics, İstinye University School of Medicine, Istanbul, Turkey

${ }^{30}$ Division of Pediatric Infectious Diseases, Department of Pediatrics, Karadeniz Technical University School of Medicine, Trabzon, Turkey

${ }^{31}$ Clinic of Pediatric Infectious Diseases, Balıkesir City Hospital, Balıkesir, Turkey

${ }^{32}$ Clinic of Pediatric Infectious Diseases, Mersin City Hospital, Mersin, Turkey

${ }^{33}$ Division of Pediatric Infectious Diseases, Department of Pediatrics, Gazi University School of Medicine, Ankara, Turkey

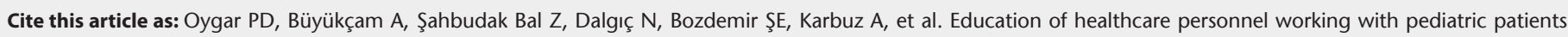
during COVID-19 pandemic within the framework of infection control. J Pediatr Inf 2020;14(4):e??-e??.

\section{Abstract}

Objective: In the early stages of any epidemic caused by new emerging pathogens healthcare personnel is subject to a great risk. Pandemic caused by SARS-CoV-2, proved to be no exception. Many healthcare workers died in the early stages of pandemic due to inadequate precautions and insufficient protection. It is essential to protect and maintain the safety of healthcare personnel for the confinement of pandemic as well as continuity of qualified healthcare services which is already under strain. Educating healthcare personnel on appropiate use of personal protective equipment (PPE) is as essential as procuring them.

Material and Methods: A survey is conducted on 4927 healthcare personnel working solely with pediatric patients from 32 different centers. Education given on PPE usage were questioned and analyzed depending on age, sex, occupation and region.

Results: Among four thousand nine hundred twelve healthcare personnel from 32 different centers $91 \%(n=4457)$ received education on PPE usage. Of those who received education only $36 \%$ was given both theoretical and applied education. Although there was no differences among different occupation groups, receiving education depended on regions.

Conclusion: It is essential to educate healthcare personnel appropiately nationwidely for the continuity of qualified healthcare services during the pandemic.

Keywords: COVID-19, healthcare personnel, personal protection, education

\section{Introduction}

With the first phenomenon of a new type of corona virus (SARS-Cov-2) which emerged in Wuhan Province of China in December 2019 and caused a pandemic in a short time, on March 11, 2020, the effect of the epidemic started to be experienced more clearly. The epidemic caused (1) death of more than 1 million people around world in a short time, affects each person living in the world differently. Since the virus first emerged, healthcare professionals have demonstrated a great
Öz

Giriş: Yeni ortaya çıkan patojenlerin neden olduğu salgınların erken dönemleri sağlık çalışanları için büyük bir risk taşımaktadır. SARS-CoV-2'nin neden olduğu pandemide de durum farklı olmamış, alınan yetersiz önlemler ve kişisel korunma eksikliği nedenleriyle pandemi başlangııında birçok sağlık çalışanı hayatını kaybetmiştir. Sağlık çalışanlarının koruması ve güvenli ortamda çalışmalarının devamlıı̆ının sağlanması sağlık hizmetlerinin aksamamasının yanında salgının sınılandırması içinde gereklidir. Kişisel koruyucu ekipmaların kullanımı ile ilgili eğitimlerin verilmesi, gerekli durumlarda güncellenmesi koruyucu ekipmanların sağlanması kadar önemlidir.

Gereç ve Yöntemler: Otuz iki farklı merkezde çocuklara sağlık hizmeti veren 4927 sağlık personeli üzerinde anket uygulanmış, kişisel koruyucu ekipman kullanımı konusunda alınan eğitim değerlendirilmiş, yaş, cinsiyet, meslek ve bölgesel farklılıkların eğitim alma üzerine etki edip etmediği değerlendirilmiştir.

Bulgular: Otuz iki farklı merkezden 4927 sağlık çalışanın katıldığı çalışmada, 4457 (\%91) sağlık çalışanın kişisel koruyucu ekipmaların kullanımı ile ilgili eğitim aldığı saptanmış, yalnızca \%36'sının hem teorik hem de uygulamalı eğitim aldığı bulunmuştur. Meslek grupları arasında eğitim alma yönünden fark görülmezken, bölgelere göre eğitim alıp almamada anlamlı fark olduğu saptanmıştır.

Sonuç: Tüm bölgelerde sağlık personelinin kişisel korunma konusunda eğitilmesi ve verilen eğitimin denetimi ve sürekliliği kaliteli sağlık hizmetlerinin devamlılığı için gereklidir.

Anahtar Kelimeler: COVID-19, sağlık çalışanı, kişisel korunma, eğitim

example of struggle all over the world. Many of healthcare professionals have died due to their assignment during epidemic (2), and a substantial majority of them feared and live to infect their families. Protecting healthcare professionals in pandemic is important in terms of preventing spread of disease as well as preventing disruption of health services. For this, healthcare personnel should be trained pracrivally continuously. Continuing education about infection form, prevention and clinical picture they cause of newly emerging or re-important pathogens is also important. In the light of the 
current and updated information, protection-related topics shall be exchanged thoroughly via sustainable training programs and associated practical components to take necessary measures for igniting reorientation.

In the COVID-19 epidemic caused by SARS-CoV-2, guidelines and practices regarding the use of special personal protection and protective equipment for healthcare professionals have been rapidly developed and necessary changes have been made over time $(3,4)$.

In our study, we aimed to ecaluate the personal protection education status given to health personnel working in health services for childhood in different regions of our country according to profession, gender, age and regions.

\section{Materials and Methods}

In the survey study, attended by a total of 32 central from 20 different provinces in seven regions of Turkey, is conducted on 4927 healthcare professionals providing healthcare services to children. In this study, it was examined whether personnel has been trained to use personal protection and personal protection equipment due to COVID-19. The survey, in which the education was questioned as theoretical, applied or both, was administered by the pediatric infectious diseases specialist working at that center (Annex-1: survey questions).

In the survey, people were asked about their underlying diseases, apart from demographic information such as their job, their years in the profession, age and gender.

Before participating in survey, each participant was required to have worked in environments with a risk of direct or indirect contact with probable or definite COVID-19 pediatric patients.

Written consent was taken from participant who provide inclusion criteria.

The study is confirmed by noninvasive ethics committee of Hacettepe University (Approval number: 2020/11-57) The study is conducted between 20 May and 15 June 2020 .

Data collected from all centers were combined in Hacettepe University Faculty of Medicine, Pediatric Infectious Diseases Science. $26^{\text {th }}$ version of IBM SPSS program was used for statistical calculations of survey results. Mean, standard deviation, and median values were used for continuous variables, while Chi-squared, Mann-Whitney U and Kruskal-Wallis Variance Alnalysis tests were used for non-continuous data.

\section{Results}

4927 healthcare professionals from 20 provinces (Ankara, Kayseri, Konya, İstanbul, Bursa, İzmir, Aydın, Manisa, Balıkesir, Denizli, Antalya, Mersin, Trabzon, Samsun, Erzurum, Van, Şanlıurfa, Gaziantep, Adıyaman, Eskişehir) in seven regions of Turkey were included in the study (Figure 1).
Annex 1. Survey

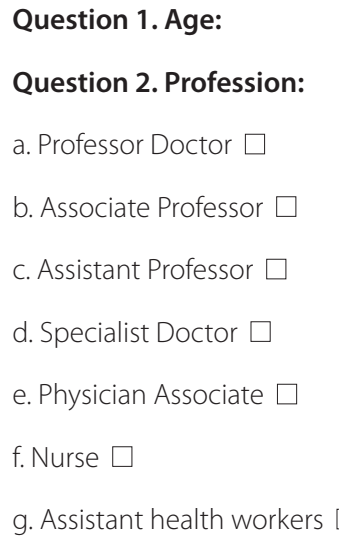

Question 6. Underlying Disease:

1. Nonexistence

2. DM $\square$

3. HT $\square$

4. Immunosupressive $\square$

5. Cancer

6. KBY $\square$

7. Asthma $\square$

8. Others

Question 7. Region Participated:

1. Central Anatolia

2. Marmara

3. Aegean $\square$

4. Eastern Anatolia $\square$

5. Southeastern Anatolia $\square$

6. Black Sea $\square$

7. Mediterranean 


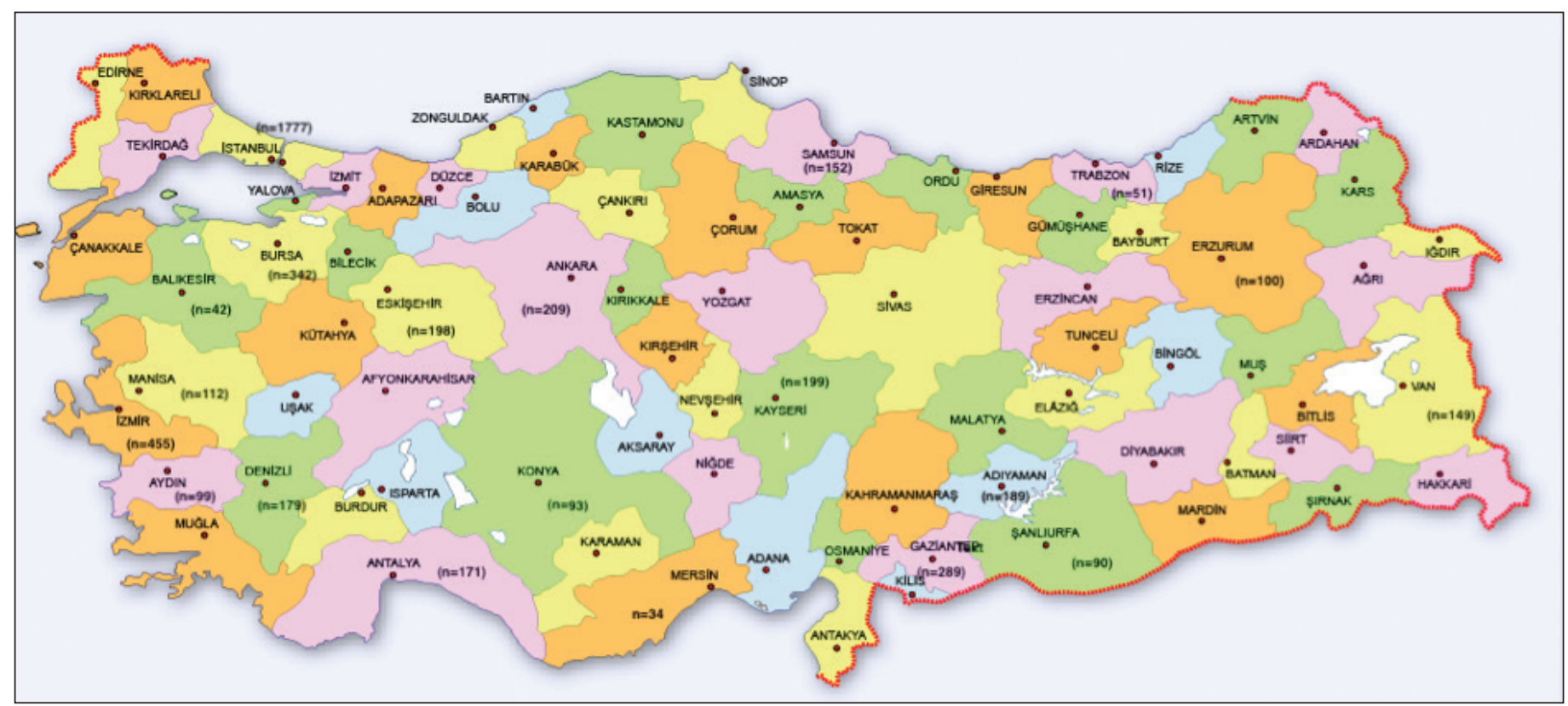

Figure 1. Number of healthcare professionals participating by provinces.

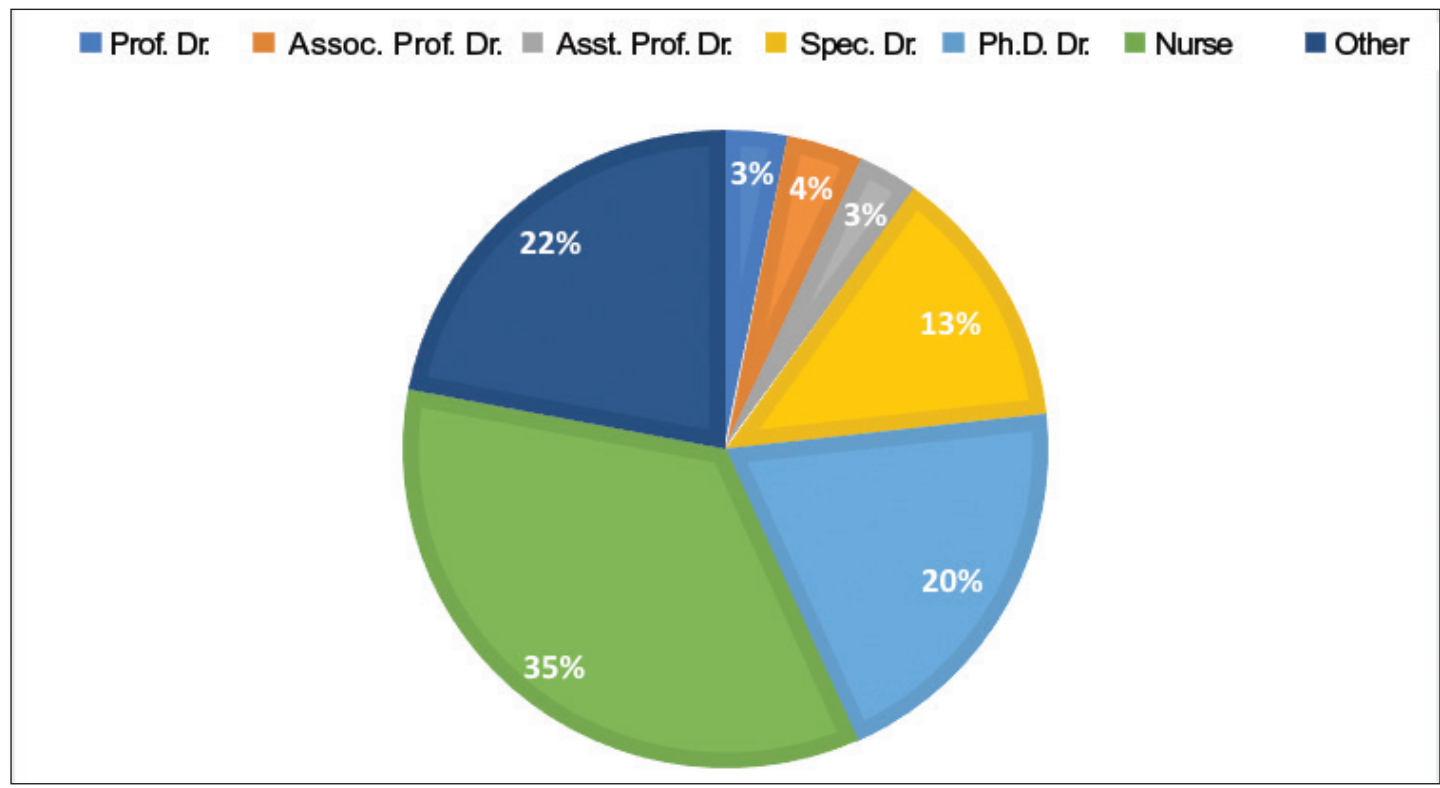

Figure 2. Distribution of healthcare professionals by profession groups.

The mean age of the participants $(n=4859)$ for whom age data was obtained was calculated as $34.4 \pm 9.07$, and the median age was 32 years (19-67 years).

Gender data of 4883 of the participating healthcare professionals were obtained. Of the healthcare professionals included in the study, 3545 (72.6\%) were female and 1338 (27.4\%) were male. Of those surveyed, 149 (3\%) were professors, 189 (3.8\%) were associate professors, 149 (3\%) were physician lecturers, 654 (13.3\%) were specialists, 983 (20\%) were assistant doctors, 1702 (34.5\%) were nurses and 1079 (21.8\%) were assistant health workers (Figure 2). According to professions groups, the average working years were calculated as the longest (28.44 years) for professor doctors and the shortest (3.57 years) for assistant doctors (Table 1).

From the survey result, it was learned that 4472 (91\%) of 4912 healthcare professionals received training on personal protection and 437 (9\%) did not receive this training.

It was learned that, of those who received training, 54.6\% $(n=2498)$ received theoretical education, $36 \%(n=1650)$ received theoretical and applied education, and $9.4 \%(n=432)$ received only applied education. Eighteen healthcare professionals were not included in the study because data on edu- 
Table 1. Training according to profession groups and forms of education taken

\begin{tabular}{|c|c|c|c|c|c|c|}
\hline \multirow[b]{2}{*}{ Profession } & \multirow[b]{2}{*}{$\begin{array}{c}\text { Number } \\
n=4904(\%)\end{array}$} & \multirow[b]{2}{*}{ Profession (year) } & \multirow[b]{2}{*}{$\begin{array}{c}\text { Untrained } \\
n=437(\% 9)\end{array}$} & \multicolumn{3}{|c|}{$\begin{array}{l}\text { Trained } \\
n=4580\end{array}$} \\
\hline & & & & $\begin{array}{c}\text { Theoretical } \\
\mathrm{n}=2498(\% 54.6)\end{array}$ & $\begin{array}{c}\text { Applied } \\
\mathrm{n}=432(\% 9.4)\end{array}$ & $\begin{array}{c}\text { Theoretical + } \\
\text { Applied } \\
n=1650(\% 36)\end{array}$ \\
\hline Professor Doctor & $149(3)$ & $28.44(15-44)$ & $15(10.1)$ & $81(58.7)$ & $8(5.8)$ & $49(35.5)$ \\
\hline Associate Professor & $188(3.8)$ & $20.32(9-40)$ & $13(7)$ & $110(60.1)$ & $14(7.7)$ & $59(32.2)$ \\
\hline Specialist Doctor & $654(13.3)$ & $13.87(1-44)$ & $65(9.9)$ & $342(56.1)$ & $60(9.8)$ & $208(34.1)$ \\
\hline Physician Associate & $983(20)$ & $3.57(0-32)$ & $92(9.4)$ & $435(47.4)$ & $71(7.7)$ & $411(44.8)$ \\
\hline Nurse & $1702(34.5)$ & $10.37(1-42)$ & $86(5.1)$ & $902(54.9)$ & $123(7.5)$ & $618(37.6)$ \\
\hline Others & $1079(21.9)$ & $10.88(0-39)$ & $145(13.5)$ & $546(57.6)$ & $136(14.3)$ & $266(36 \%)$ \\
\hline
\end{tabular}

Table 2. Presence and distribution of an underlying disease of the participants

\begin{tabular}{|c|c|c|c|c|c|c|c|c|c|c|c|}
\hline \multirow[b]{2}{*}{ Profession } & \multirow[b]{2}{*}{ n (\%) } & \multirow[b]{2}{*}{ Age (mean) } & \multirow{2}{*}{$\begin{array}{c}\text { Gender } \\
\text { F/M }\end{array}$} & \multicolumn{8}{|c|}{ Underlying Disease } \\
\hline & & & & Nonexistence & HT & DM & Immunosupressive & Cancer & KBY & Asthma & Other \\
\hline Associate Professor & $188(3.8)$ & $44.17(36-64)$ & $134 / 50$ & 140 & 10 & 12 & 2 & 2 & 0 & 7 & 13 \\
\hline Assistant Professor & $149(3)$ & $36.01(25-59)$ & $108 / 41$ & 116 & 4 & 8 & 1 & 0 & 0 & 6 & 13 \\
\hline Nurse & $1702(34.5)$ & $32.38(19-62)$ & $1460 / 211$ & 1377 & 34 & 36 & 11 & 9 & 1 & 68 & 157 \\
\hline Assistant health workers & $1079(21.9)$ & $37.77(19-64)$ & $622 / 42$ & 841 & 40 & 34 & 6 & 8 & 0 & 50 & 87 \\
\hline Total & 40.904 & & $3454 / 911$ & $3948(80.1)$ & 118 & 150 & 26 & 24 & 1 & 189 & 303 \\
\hline
\end{tabular}

cation did not obtain. While it was observed that those who did not receive education were mostly associate professors (14.2\%), assistant health workers (13.5\%) took the second place. The rate of not having education was observed at least among nurses (5.1\%). Statistical discrepancy did not find among professions in terms of education or not $(p=0.17)$. Gender and years in profession also had no effect on education or not ( $p=0.11$ ve $p=0.82$ ). Significant difference were determined between regions in terms of education $(p<0.05)$. Most of the participants were healthy young health professionals, $80 \%$ stated that they did not have an underlying disease (Table 2). Significant differences were not determined between underlying diseases and education or not $(p=0.25)$.

\section{Discussion}

Healthy healthcare professionals have important roles in limiting the epidemic, as well as providing services in pandemic. The extent and rate of transmission of the COVID-19 pandemic reached very high levels in our country in a period of six months with the number of people it affected.
As of November 4, 2020, the total number of cases in our country was reported as 384.509 (5). The importance of protecting healthcare professionals and being able to continue their assignment, especially in the early stages of the pandemic, has been once again seen. It is necessary to provide the necessary training and ensure continuity for the correct use of protective equipment.

In the survey we conducted, it was determined that $8.9 \%$ of the healthcare professionals did not receive training, and $54.6 \%$ received only theoretical training.

Apart from providing personal protective equipment, their correct use should also be controlled. Besides healthcare professionals with COVID-19 contact should be monitored and screened continuously and surveillance studies should be carried out for the isolation of infected healthcare personnel $(6,7)$. Care, permission, treatment and psychological support of health personnel in case of illness should not be forgotten. In this respect, in our country, the fact that the COVID guide was published in January 2020 before the first case was detected can be considered as an advantage (8). World Health 
Organization has put online training sets (web page) into practice for this purpose. However, these practices were possible in April - May 2020, after the period when the COVID-19 epidemic affected Europe greatly and many healthcare professionals got the disease (8).

In cases where new infectious diseases emerge, healthcare professionals are at risk more than anyone else, especially until the transmission dynamics of the new disease are identified. The situation was no different in the COVID-19 epidemic. As the number of transmission increases in the community, it becomes difficult to determine whether the transmission of healthcare professionals originates from the community or hospital.

The protection of healthcare workers can be achieved by the full implementation of infection control measures and the correct use of personal protective equipment. The way to achieve these is through continuous training and supervision. In addition, early detection and early isolation of asymptomatic or subclinical cases will reduce transmission to healthcare professionals working in risky areas. In the COVID-19 epidemic, the protection of healthcare workers, who constitute the most risky group, is essential to ensure the continuity of health systems that are already challenging all over the world.

Ethics Committe Approval: The ethical approval for this study was obtained from Hacettepe University Non-Invasive Clinical Research Ethics Committee (Decision no: 2020/11-57 Date: 20.05.2020).

Informed Consent: Since it is a questionnaire for adults, patient consent is not required.

Peer-review: Externally peer-reviewed.

Author Contributions: Concept - AK; Design - AK, PDO; Supervision - AK; Resource - PDO; Data Collection and/or Processing - All of authors; Analysis and/or Interpretation - PDO; Literature Search PDO; Writing - PDO; Critical Review - AK.

Conflict of Interest: No conflict of interest was declared by the authors.

Financial Disclosure: The authors declared that this study has received no financial support.

\section{References}

1. World Health Organization (WHO). Available from: https://Www. who.int/emergencies/diseases/novel-coronavirus-2019/situation-reports11-18. Accessed: October 2020. [CrossRef]

2. $M$ Zhan, $Y$ Qin, $X X$ Xue, $S$ Zhu. Death from Covid-19 of 23 health care workers in China. N Engl J Med 2020;382:2267-8. [CrossRef]

3. World Health Organization (WHO). Use of personal protective equipment (PPE) for coronavirus disease (COVID-19) Available from: http:// www.WorldHealthOrganization-2020-apps.who.int. Accessed: 19 March 2020. [CrossRef]

4. Centers for Disease Control and Prevention (CDC). Using Personal Protective Equipment (PPE). Available from: https://www.cdc.gov/coronavirus/2019-ncov/hcp/using-ppe.html. Accessed: 19 Agust 2020. [CrossRef]

5. T.C. Sağlık Bakanlığı COVID-19 resmî sitesi. Available from: https:// www.covid19. saglik.gov.tr. Erişim tarihi: 4 Kasım 2020. [CrossRef]

6. Chang D, Xu H, Rebaza A, Sharma L, Dela Cruz CS. Protecting healthcare workers from subclinical coronavirus infection. Lancet Respir Med 2020;8(3):e13. [CrossRef]

7. Wang XH, Pan ZY, Cheng ZS. Association between 2019-nCoV transmission and $N 95$ respirator use. J Hosp Infect 2020;105(1):104-5. [CrossRef]

8. World Health Organization (WHO). How To Put On And Take Off Personal Protective Equipment (PPE). WHO. Available from: https://www. who.int/csr/resources/publications/putontakeoffPPE/en Accessed: 22 April 2020. [CrossRef] 